\title{
Influence of mountain spruce forest dieback on snow accumulation and melt
}

\author{
Martin Bartík $^{1 *}$, Ladislav Holko ${ }^{2}$, Martin Jančo ${ }^{1,3}$, Jaroslav Škvarenina ${ }^{1}$, Michal Danko ${ }^{2}$, \\ Zdeněk Kostka ${ }^{2}$ \\ ${ }^{1}$ Department of Natural Environment, Faculty of Forestry, Technical University in Zvolen, T. G. Masaryka 24, 96001 Zvolen, Slovakia. \\ ${ }^{2}$ Institute of Hydrology, Slovak Academy of Sciences, Dúbravská cesta 9, 84104 Bratislava, Slovakia. \\ ${ }^{3}$ Faculty of Ecology and Environmental Sciences, Technical University in Zvolen, T. G. Masaryka 24, 96001 Zvolen, Slovakia. \\ ${ }^{*}$ Corresponding author. E-mail: bartikmartin@gmail.com
}

\begin{abstract}
Large-scale forest dieback was reported in recent decades in many parts of the world. In Slovakia, the most endangered species is Norway spruce (Picea Abies). Spruce dieback affects also indigenous mountain forests. We analysed changes in snow cover characteristics in the disturbed spruce forest representing the tree line zone (1420 m a.s.1.) in the Western Tatra Mountains, Slovakia, in five winter seasons 2013-2017. Snow depth, density and water equivalent (SWE) were measured biweekly (10-12 times per winter) at four sites representing the living forest (Living), disturbed forest with dead trees (Dead), forest opening (Open) and large open area outside the forest (Meadow). The data confirmed statistically significant differences in snow depth between the living and disturbed forest. These differences increased since the third winter after forest dieback. The differences in snow density between the disturbed and living forest were in most cases not significant. Variability of snow density expressed by coefficient of variation was approximately half that of the snow depth. Forest dieback resulted in a significant increase (about 25\%) of the water amount stored in the snow while the snowmelt characteristics (snowmelt beginning and time of snow disappearance) did not change much. Average SWE calculated for all measurements conducted during five winters increased in the sequence Living $<$ Dead $<$ Meadow < Open. SWE variability expressed by the coefficient of variation increased in the opposite order.
\end{abstract}

Keywords: Snow characteristics; Forest dieback; Norway spruce; Mountains; Degree-day model.

\section{INTRODUCTION}

Forest significantly influences the hydrological cycle (Bredemeier et al., 2010; Jewitt, 2005; Mráček and Krečmer, 1975). Part of precipitation intercepted by the forest is evaporated back to the atmosphere (Chang, 2006). Interception also changes the spatial distribution of precipitation under the canopy (e.g. Bartík et al., 2016; Holko et al., 2009; Lundberg et al., 1998). On the contrary, horizontal precipitation captured by the forest can represent an important component of the water and hydrochemical balance (Elias et al., 1995; Fišak et al., 2001; Mind'áš and Škvarenina, 1995). Moreover, forest significantly affects precipitation partitioning into overland and subsurface flow through its influence on the soil (Gömöryová et al., 2013; Gömöryová et al., 2017; Stähli et al., 2011). Hence, forest change has manifold hydrological consequences, the effects of which are not easy to predict in detail (Bredemeier et al., 2010; Michalova et al., 2017; Rogger et al., 2017).

Forest affects also the snow accumulation and melt. The differences in snow characteristics in the forest and in nearby open areas have been observed for more than a century (e.g. Church, 1914). A number of studies compared snow in the forest and forest clearings or specifically addressed the influence of forest management practices, i.e. direct human interventions (e.g. Andreson, 1963; Ellis et al., 2010; Garstka et al., 1958; Golding and Swanson, 1986; Kittregde, 1953; Koivusalo and Kokonen, 2002; Kuusisto, 1980; Mayer et al., 1997; Stähli et al., 2000; Swanson and Golding, 1982; Troendle and King, 1987; Zelený, 1971). The results of empirical studies of changes in forest cover and associated changes in snow accumulation and ablation rates were reviewed by Varhola et al. (2010). More recent studies addressed also the effects of forest dieback, i.e. natural disturbances, on snow characteristics. They used measured data or modelling to study the effects of dieback caused by bark beetle or forest fires (e. g. Bartík et al., 2014; Boon, 2012;
Harpold et al., 2014; Jeníček et al., 2018; Perrot et al., 2012; Pugh and Small, 2012).

Large-scale forest disturbances were recently reported in Europe (Mezei et al., 2014, 2017; Seidl et al., 2011) and a number of authors have pointed out the hydrological consequences of forest dieback (e.g. Adams et al., 2012; Vido et al., 2015; Winkler et al., 2014). In Slovakia, forests cover approximately $40 \%$ of the country. Extensive areas of Slovak forests were recently affected by dieback as well (Grodzki et al., 2006; Jakuš et al., 2011). Norway spruce (Picea Abies (L.) Karst.), the most abundant coniferous tree in Slovakia (about 26\% of all forest tree species), is one of the most endangered species, especially owing to its high sensitivity to increasing air temperature. Dieback does not occur only in areas where spruce was introduced by people. It is documented also in indigenous mountain forests (Janda et al., 2016; Parobeková et al., 2016) and in areas which were until now relatively less affected by human activities (Fleischer et al., 2017). Because such forests often occur in headwater catchments, their change can influence snow accumulation and melt and consequently runoff formation and discharge regimes in downstream areas. Understanding the local effects of such changes on snow accumulation and melt requires studies based on local data measured over a long time.

This article presents the results of measurements of snow depth, density and water equivalent from the highest part of the Carpathian Mountains during five winters. It differs from previous studies in that the measurements were conducted over the entire winter seasons with a relatively high frequency (approximately every two weeks). The overall objective of our study is to analyse the influence of the mountain spruce forest dieback on snow accumulation and melt. The article is organised so that we first compare snow characteristics and their variability at sites with different land cover (living and disturbed forest, forest opening and a large open area outside the forest). Then we evaluate the influence of different stand characteristics (land 
use) on snow accumulation and melt. The results could be useful in the assessment of regional snow cover development in similar snowmelt dominated headwater catchments affected by forest dieback.

\section{MATERIAL AND METHODS Study area}

The study was conducted at research plot Červenec $\left(49.183617^{\circ} \mathrm{N}, 19.641944^{\circ} \mathrm{E}\right.$, elevation $1420 \mathrm{~m}$ a.s.l.) in the Western Tatra Mountains, northern Slovakia. The plot is located in the Jalovecký creek catchment which is the subject of long-term hydrological research devoted also to snow cover (Holko and Kostka, 2010). The bedrock at the research plot is formed by limestone, marlstone, claystone and dolomite. The soil is classified as Cambisol and has high stoniness (Hlaváčiková et al., 2016). The forest at the plot is representative of the tree line zone in the highest part of the Carpathian Mountains. Although the forest at the plot was significantly affected by human activities in the past, today it is classified as dominantly natural (Celer, 2013). It is composed solely of Norway spruce. The age of the trees is more than 130 years (Oreňák et al., 2013). Places with sparse density of the forest are overgrown with rowan (Sorbus aucuparia L.). The understory is represented by bilberry (Vaccinium myrtyllus L.); raspberry (Rubus idaeus L.) occurs in the open area. Part of the forest died in summer 2012 as a result of the bark beetle (Ips typhographus L.) outbreak. Branches of the dead trees are covered with lichen "tree moss" (Pseudevernia furfuracea (L. Zopf.).

\section{Data}

Snowpack measurements in the open area and in the forest have been conducted since the 1990's (Holko et al., 2009). The results presented in this article are based on data from the new snow courses established after the forest dieback since winter 2013. We present data from five winters (2013-2017). A "winter" is defined as the period from November through the following May. For example, winter 2013 is represented by data measured from November 2012 until May 2013.

The snow courses are located in the living forest (hereafter denoted as „Living“), disturbed forest with dead trees (Dead), forest opening (Open) and in the large open area outside the forest (Meadow). The size of the forest opening is $1 \mathrm{H}-2 \mathrm{H}$, where $\mathrm{H}$ is tree height. Snow depth (SD) and water equivalent (SWE) were measured at the snow courses every two weeks (biweekly) depending on weather conditions (10-12 times per winter). Snow density was calculated from snow depth and snow water equivalent at the snow course.

SWE was measured using a fibre glass snow tube with a cross section area of $50 \mathrm{~cm}^{2}$, which was weighed with a digital scale with resolution of 10 grams. SD was measured by a graduated rule with resolution of $1 \mathrm{~cm}$.

Snow courses in the open area, i.e. at sites Open and Meadow, were located 50 meters and 300 meters away from the snow courses at forested sites (Living and Dead), respectively.

SD was measured every meter at 31 points at each snow course in the forest sites (Living and Dead). SWE in the forest was measured every five meters, i.e. seven values were obtained at each snow course (Fig. 1). In the open area, 20 SD measurements and 3 SWE measurements were made at each snow course (sites Open and Meadow). Mean values for the snow courses on individual dates were calculated as follows:

- mean SD value was calculated from 31 (forest) and 20 values (open area),

- mean snow density was calculated from 7 (forest) and 3 (open area) SWE values and the corresponding SD values,

- the SWE for the snow course was obtained by multiplication of the mean SD by the mean snow density.

Precipitation at the snow courses was measured manually by the standard rain gauges of the Slovak Hydrometeorological Institute with orifice area $500 \mathrm{~cm}^{2}$. Three gauges were installed in the forest to capture precipitation patterns at the typical forest locations, i.e. in the forest opening, the drip zone and the nearstem zone (Holko et al., 2009).

Daily precipitation and air temperature data from the automatic weather station equipped with a weighing rain gauge located near the snow courses were used in snow accumulation and melt modelling. The weather station is located in the open area. Therefore, measured precipitation and air temperature from the station were directly used in the modelling for the Meadow and Open sites. Model input precipitation for sites Dead and Living was modified according to the throughfall measurements conducted at both sites. The throughfall values calculated from the readings of raingauges located under the trees and in the forest windows provided precipitation correction coefficients. The coefficients were applied backwards to calculate the input daily precipitation at sites Dead and Living since the previous day with throughfall data. Comparison of air temperature measured at the weather station with that measured under the nearby dense spruce tree stand showed that air temperature under the canopy was on average $1{ }^{\circ} \mathrm{C}$ lower than that in the open area. This value was therefore used to prepare the model input air temperature data for the site Living.

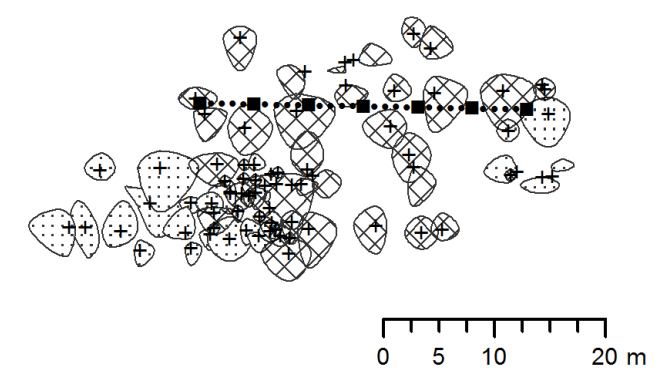

Legend

- Snow depth measurements

- Snow density measurements

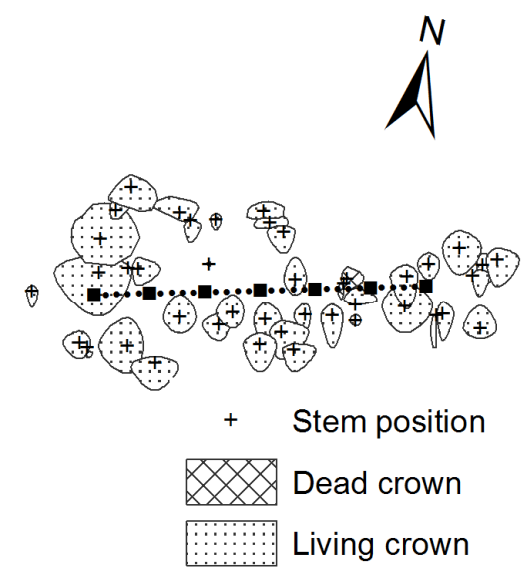

Fig. 1. Snow depth and density measurements at forested sites (Dead, Living). 


\section{Methods}

Climatic characteristics of the studied winters were first evaluated using the total precipitation amount and sum of positive daily air temperature from December to March. The values for individual winters were plotted as anomalies (Holko et al., 2012), i.e. as deviations from the long-term mean values for the period 1989-2017. Such presentation allows fast identification of extreme winters in the time series data. Climatic conditions important for snow cover evolution, i.e. precipitation amount and potential snowmelt in the study winters can also be quickly assessed and compared. Temporal evolution of SD and snow density at all sites in the five study winters was compared. Variability of SD and snow density along each snow course was expressed by standard deviations to obtain the absolute values in $\mathrm{cm}$ and $\mathrm{kg} . \mathrm{m}^{-3}$, respectively. The use of standard deviation helps to perceive the importance of the variability when compared to the temporal evolution of SD or snow density (as in Figs. 3 and 5). Comparison of variability in snow characteristics among the sites (snow courses) and on different dates was based on coefficients of variation $(\mathrm{Cv})$. Box-whisker plots were used to compare the data measured at individual snow courses over entire winters.

Mean values of SD and snow density for each snow course and day with measurements as well as for the entire study period were compared using the Student paired test. The aim was to test whether the two compared data sets were significantly different from each other at a significance level of $95 \%$. Significantly different data sets were marked in results with „x“ (e.g. Table 2). Statistical analysis was carried out with Statistica 10 and Statgraphics Centurion XVI.I.

Biweekly measurements at snow courses may not capture the maximum seasonal snow water equivalent (SWE) and provide correct snowmelt characteristics (onset, termination). Therefore, snow accumulation and melt modelling was used to provide daily values of SWE. A simple degree-day model was used. Snow accumulation was simulated if the mean daily air temperature during days with precipitation was below the threshold temperature. Snow melt was calculated according to the following well-known formula:

$M=D D F\left(T-T_{c r i t}\right)$

where $M$ is the snowmelt [mm], $D D F$ is the degree-day factor $\left[\mathrm{mm} .{ }^{\circ} \mathrm{C}^{-1}\right.$.day $\left.{ }^{-1}\right], T$ is the mean daily air temperature $\left[{ }^{\circ} \mathrm{C}\right]$ and $T_{\text {crit }}\left[{ }^{\circ} \mathrm{C}\right]$ is the threshold air temperature above which the snow starts to melt.

The threshold air temperature above which all precipitation falls as rainfall, threshold air temperature at which the snowmelt starts and the temporally variable degree-day factor were used to fit the simulated and measured SWE values. The aim of the modelling was solely to fit the simulated and measured values during the time of maximum SWE and the snowmelt period (i.e. not to transfer the model to other sites or time periods or evaluate the calibrated degree-day factors). Therefore, model parameters were variable in time and different for each site and winter. After the simulations we have calculated the Kling-Gupta efficiency coefficient KGE (Gupta et al., 2009):

$$
\begin{aligned}
& K G E=1-\sqrt{(r-1)^{2}+(\alpha-1)^{2}+(\beta-1)^{2}} \\
& \alpha=\frac{\sigma_{\text {sim }}}{\sigma_{o b s}} \quad \beta=\frac{\mu_{\text {sim }}}{\mu_{o b s}}
\end{aligned}
$$

where $r$ is the linear correlation coefficient, $\sigma$ is standard deviation, $\mu$ is arithmetic mean and sim and obs represent simulated and observed values, respectively.

KGE was used instead of the more common Nash Sutcliffe coefficient (Nash and Sutcliffe, 1970), because it allows identification of the origin of model errors.

The degree-day model was run at a daily time step for the period November 1st to May 5th. Model parameters were calibrated by the trial and error approach. Simulated SWEs were visually compared with measured values during model calibration. Maximum SWE, dates of snowmelt onset and termination and snowmelt duration were then obtained from the modeled data for each site and winter.

\section{RESULTS}

\section{Climatic characteristics of winters 2013-2017}

The long-term average (1989-2017) of precipitation in cold months (December to March) at the research plot is about 400 mm (Fig. 2). About 25 days during the same period had daily mean air temperature above zero. The long-term average of the sum of positive air temperature from December to March is about $54^{\circ} \mathrm{C}$. Fig. 2 shows that above-average precipitation occurred in winter 2013. At the same time, the sum of positive air temperatures was below-average. Thus, winter 2013 had the most favourable conditions for snow accumulation out of the five studied winters. Winter 2014 represented the opposite situation, namely below-average precipitation and aboveaverage sum of positive daily temperatures. Fig. 2 reveals that shifting from wet to dry or cold to warm in successive winters is quite common in the study area. However, winter 2014 was unique for its unusually dry and warm weather. Satellite data confirmed that all of Slovakia was extremely snow-poor (Krajčí et al., 2016). In winters 2015-2017, total precipitation and sum of positive air temperatures were close to long-term averages.

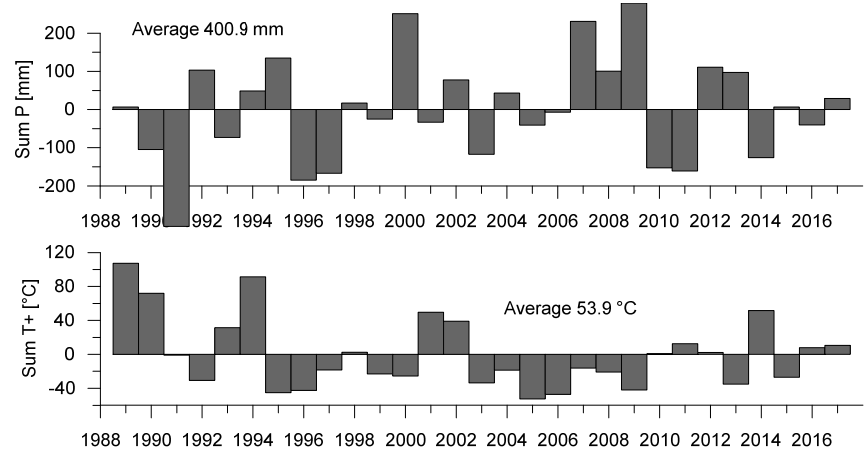

Fig. 2. Anomalies of total precipitation and positive air temperature of winter periods (December to March) at the research plot according to data from the meteorological station located in the open area.

\section{Snow depth}

Annual maximum snow depths at different sites exceeded $80-100 \mathrm{~cm}$ and standard deviations for most days with measurements were under $10 \mathrm{~cm}$ (Fig. 3). Coefficients of variations $(\mathrm{Cv})$ of the SD calculated for individual dates with measurements mostly did not exceed 0.3 . The highest SD was almost always measured in the forest opening (Open). This pattern is well known and reflects increased snow accumulation at sites protected from the wind (e.g. Troendle and King, 1985). SD in the disturbed forest (Dead) was almost always higher than in the living forest (Living), a result of the interception decrease 


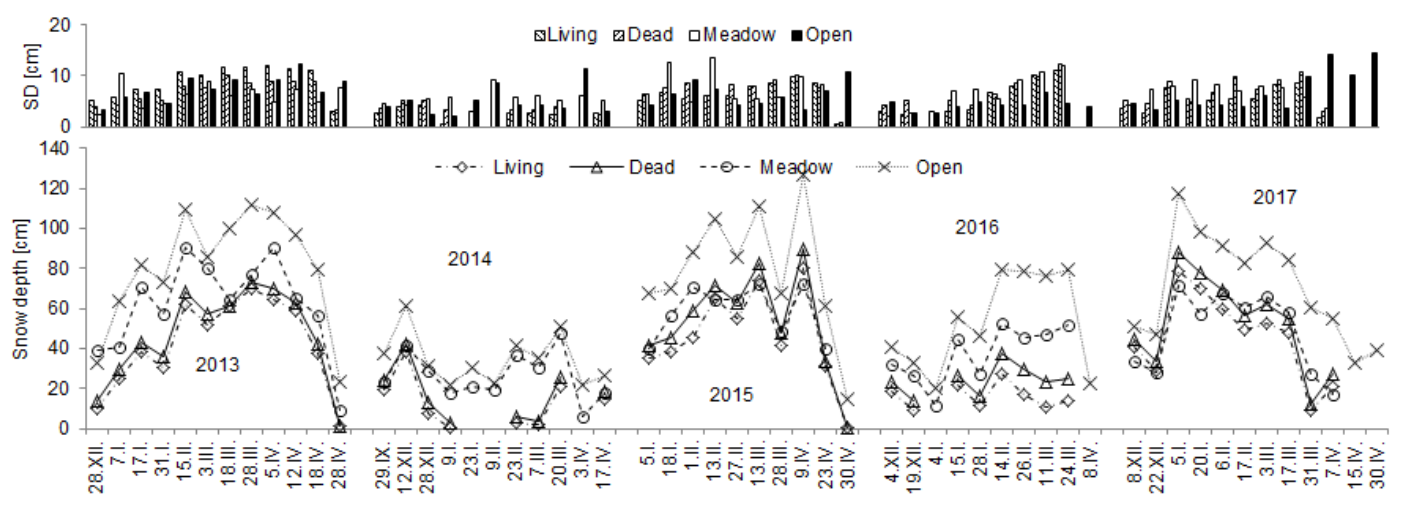

Fig. 3. Mean snow depth and its variability (SD in the figure represents the standard deviation) at all sites and on all days with measurements in winters 2013-2017.

Table 1. Snow depth $[\mathrm{cm}]$ and its variability for the entire winter season.

\begin{tabular}{|c|c|c|c|c|c|c|c|c|c|c|c|c|c|c|c|c|c|c|c|c|c|c|c|c|}
\hline & \multicolumn{4}{|c|}{2013} & \multicolumn{4}{|c|}{2014} & \multicolumn{4}{|c|}{2015} & \multicolumn{4}{|c|}{2016} & \multicolumn{4}{|c|}{2017} & \multicolumn{4}{|c|}{ 2013-2017 } \\
\hline & 言 & 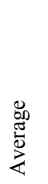 & 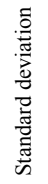 & 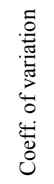 & 謍 & 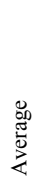 & 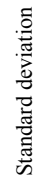 & 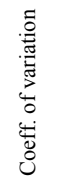 & 音 & 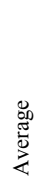 & 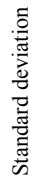 & 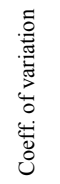 & 壳 & 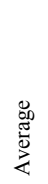 & 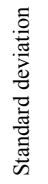 & 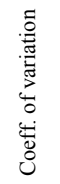 & 壳 & 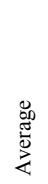 & 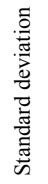 & 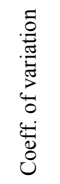 & 言 & 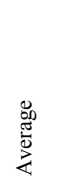 & 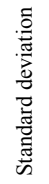 & 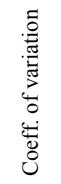 \\
\hline Living & 12 & 43 & 23 & 0.53 & 8 & 13 & 13 & 0.97 & 10 & 47 & 23 & 0.50 & 8 & 16 & 6 & 0.38 & 10 & 46 & 22 & 0.47 & 48 & 35 & 24 & 0.67 \\
\hline Dead & 12 & 47 & 23 & 0.50 & 8 & 17 & 14 & 0.79 & 10 & 53 & 26 & 0.49 & 8 & 24 & 8 & 0.31 & 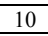 & 53 & 24 & 0.45 & 48 & 41 & 25 & 0.61 \\
\hline Meadow & 12 & 62 & 24 & 0.38 & 11 & 26 & 12 & 0.46 & 9 & 59 & 13 & 0.23 & 9 & 38 & 14 & 0.37 & 10 & 49 & 20 & 0.41 & 51 & 47 & 22 & 0.46 \\
\hline Open & 12 & 81 & 29 & 0.36 & 11 & 35 & 13 & 0.37 & 10 & 80 & 31 & 0.39 & 10 & 53 & 24 & 0.45 & 12 & 71 & 7 & 0.38 & 55 & 64 & 30 & 0.47 \\
\hline Total & 48 & 58 & 28 & 0.49 & 38 & 24 & 15 & 0.62 & 39 & 60 & 27 & 0.45 & 35 & 34 & 21 & 0.60 & 42 & 55 & 25 & 0.45 & 202 & 47 & 28 & 0.58 \\
\hline
\end{tabular}

Table 2. Statistical significance of the differences in mean snow depth among the sites.

\begin{tabular}{|c|c|c|c|c|c|c|c|c|c|c|c|c|c|c|c|c|c|c|c|c|c|c|c|c|c|c|c|c|c|c|c|c|c|c|c|}
\hline & \multicolumn{12}{|c|}{2013} & \multicolumn{12}{|c|}{2014} & \multicolumn{11}{|c|}{2015} \\
\hline & $\begin{array}{l}\dot{\bar{x}} \\
\dot{\infty} \\
\dot{\sim}\end{array}$ & $\stackrel{-}{\sim}$ & $\stackrel{\dot{I}}{\check{I}}$ & $\underset{m}{\dot{m}}$ & $\begin{array}{l}\exists \\
\ddot{\sim}\end{array}$ & $\begin{array}{l}\dot{\Xi} \\
\dot{m}\end{array}$ & $\begin{array}{l}\Xi \\
\infty \\
\infty\end{array}$ & $\begin{array}{l}\underset{\Xi}{\Xi} \\
\stackrel{\infty}{\sim}\end{array}$ & $\begin{array}{l}\dot{z} \\
\text { in }\end{array}$ & $\begin{array}{l}\geq \\
\beth\end{array}$ & $\begin{array}{l}\dot{2} \\
\infty \\
\infty\end{array}$ & $\begin{array}{l}\vec{i} \\
\stackrel{\infty}{\sim}\end{array}$ & & $\begin{array}{ll}\dot{x} & \bar{x} \\
2 & \end{array}$ & $\begin{array}{ll}\overline{\bar{x}} & \bar{x} \\
\dot{x} & \infty \\
\dot{v} & \infty\end{array}$ & $\begin{array}{ll}\dot{B} & \\
\dot{a} & \\
\dot{0} & \\
& \end{array}$ & कृ & $\dot{\vec{\lambda}}$ & $\dot{\vec{a}}$ & $\begin{array}{l}\overrightarrow{\vec{\nu}} \\
\dot{\vec{\nu}}\end{array}$ & $\underset{\sim}{\Xi}$ & $\begin{array}{l}\dot{\Xi} \\
\dot{\sim}\end{array}$ & $\begin{array}{l}\dot{n} \\
\dot{n}\end{array}$ & $\begin{array}{l}\geq \\
\stackrel{2}{\Xi}\end{array}$ & is & & & 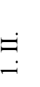 & $\begin{array}{l}\dot{=} \\
\dot{g}\end{array}$ & 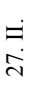 & $\begin{array}{l}\dot{\Xi} \\
\dot{\Omega}\end{array}$ & $\begin{array}{l}\dot{\Xi} \\
\dot{\infty} \\
\stackrel{\sim}{\sim}\end{array}$ & $\begin{array}{l}z \\
a\end{array}$ & $\begin{array}{l}\vec{\lambda} \\
\ddot{\lambda}\end{array}$ & $\begin{array}{l}\dot{Z} \\
\dot{0}\end{array}$ \\
\hline Living vs. Meadow & $\mathrm{x}$ & $\mathrm{x}$ & $\mathrm{x}$ & $\mathrm{x}$ & $\mathrm{x}$ & $\mathrm{x}$ & & $\mathrm{x}$ & $\mathrm{x}$ & $\mathrm{x}$ & $\mathrm{x}$ & $\mathrm{x}$ & & $\mathrm{x}$ & $\mathrm{x}$ & $\mathrm{X} \quad \mathrm{x}$ & $\mathrm{x}$ & & & $\mathrm{x}$ & $\mathrm{x}$ & $\mathrm{x}$ & & $\mathrm{x}$ & 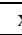 & & & $\mathrm{x}$ & & $\mathrm{x}$ & & $\mathrm{x}$ & $\mathrm{x}$ & $\mathrm{x}$ & \\
\hline Living vs. Open & $\mathrm{x}$ & $\mathrm{x}$ & $\mathrm{x}$ & $\mathrm{x}$ & $\mathrm{x}$ & $\mathrm{x}$ & $\mathrm{x}$ & $\mathrm{x}$ & $\mathrm{x}$ & $\mathrm{x}$ & $\mathrm{x}$ & $\mathrm{x}$ & & $\mathrm{x} \quad \mathrm{X}$ & $\begin{array}{ll}x & x\end{array}$ & $\mathrm{X} \quad \mathrm{X}$ & $\mathrm{x}$ & & & $\mathrm{x}$ & $\mathrm{x}$ & $\mathrm{x}$ & & $\mathrm{x}$ & $Y$ & & & $\mathrm{x}$ & $\mathrm{x}$ & $\mathrm{x}$ & $\mathrm{x}$ & $\mathrm{x}$ & $\mathrm{x}$ & $\mathrm{x}$ & \\
\hline Dead vs. Meadow & $\mathrm{x}$ & $\mathrm{x}$ & $\mathrm{x}$ & $\mathrm{x}$ & $\mathrm{x}$ & $\mathrm{x}$ & & & $\mathrm{x}$ & & $\mathrm{x}$ & $\mathrm{x}$ & & & & $\mathrm{X} \quad \mathrm{x}$ & $\mathrm{x}$ & & & $\mathrm{x}$ & $\mathrm{x}$ & $\mathrm{x}$ & & & & & & $\mathrm{x}$ & $\mathrm{x}$ & & $\mathrm{x}$ & & $\mathrm{x}$ & $\mathrm{x}$ & \\
\hline Dead vs. Open & $\mathrm{x}$ & $\mathrm{x}$ & $\mathrm{x}$ & $\mathrm{x}$ & $\mathrm{x}$ & $\mathrm{x}$ & $\mathrm{x}$ & $\mathrm{x}$ & $\mathrm{x}$ & $\mathrm{x}$ & $\mathrm{x}$ & $\mathrm{x}$ & & $\mathrm{x}$ & $\mathrm{x}$ & $\mathrm{X} \quad \mathrm{x}$ & $\mathrm{x}$ & & & $\mathrm{x}$ & $\mathrm{x}$ & $\mathrm{x}$ & & $\mathrm{x}$ & 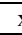 & & & $\mathrm{x}$ & $\mathrm{x}$ & $\mathrm{x}$ & $\mathrm{x}$ & $\mathrm{x}$ & $\mathrm{x}$ & $\mathrm{x}$ & \\
\hline \multirow{3}{*}{ Meadow vs. Open } & $\mathrm{x}$ & $\mathrm{x}$ & $\mathrm{x}$ & $\mathrm{x}$ & $\mathrm{x}$ & $\mathrm{x}$ & $\mathrm{x}$ & $\mathrm{x}$ & $\mathrm{x}$ & $\mathrm{x}$ & $\mathrm{x}$ & $\mathrm{x}$ & & $x$ & $\mathrm{x}$ & & $\mathrm{x}$ & $\mathrm{x}$ & & $\mathrm{x}$ & $\mathrm{x}$ & $\mathrm{x}$ & $\mathrm{x}$ & $\mathrm{x}$ & & & & $\mathrm{x}$ & $\mathrm{x}$ & $\mathrm{x}$ & $\mathrm{x}$ & $\mathrm{x}$ & $\mathrm{x}$ & $\mathrm{x}$ & \\
\hline & \multicolumn{12}{|c|}{2016} & \multicolumn{11}{|c|}{2017} & & & & & & & & & & & & \\
\hline & $\begin{array}{l}\dot{\nabla} \\
\dot{\nabla}\end{array}$ & $2 \cdot \bar{x}$ & & $\dot{n}$ & $\stackrel{\dot{\infty}}{\sim}$ & $\begin{array}{l}\dot{\Xi} \\
\dot{\Xi}\end{array}$ & $\begin{array}{l}\dot{=} \\
\dot{\sim}\end{array}$ & $\begin{array}{l}\dot{\Xi} \\
\dot{\Xi}\end{array}$ & $\begin{array}{l}\dot{\Xi} \\
\dot{\sim}\end{array}$ & $\underset{\infty}{\dot{\infty}}$ & & $\begin{array}{l}\dot{\bar{x}} \\
\dot{\infty}\end{array}$ & $\begin{array}{l}\bar{x} \\
\ddot{\sim}\end{array}$ & $\dot{\text { in }}$ & $\dot{\check{N}}$ & $\stackrel{\dot{\Xi}}{\dot{0}}$ & $\stackrel{\Xi}{\doteq}$ & $\underset{\dot{\Xi}}{\dot{\Xi}}$ & $\begin{array}{l}\Xi \\
\Xi \\
\Xi\end{array}$ & & $\dot{E}$ & $\frac{i}{i}$ & $\begin{array}{l}\geq \\
i \\
i\end{array}$ & & & & & & & & & & & & \\
\hline Living vs. Dead & $\mathrm{x}$ & $\mathrm{x}$ & & $\mathrm{x}$ & $\mathrm{x}$ & $\mathrm{x}$ & $\mathrm{x}$ & $\mathrm{x}$ & $\mathrm{x}$ & & & $\mathrm{x}$ & $\mathrm{x}$ & $\mathrm{x}$ & $\mathrm{x}$ & $\mathrm{x}$ & $\mathrm{x}$ & $\mathrm{x}$ & $\mathrm{x}$ & & & $\mathrm{x}$ & & & & & & & & & & & & & \\
\hline Living vs. Meadow & $\mathrm{x}$ & $\mathrm{x}$ & & $\mathrm{x}$ & $\mathrm{x}$ & $\mathrm{x}$ & $\mathrm{x}$ & $\mathrm{x}$ & $\mathrm{x}$ & & & $\mathrm{x}$ & & $\mathrm{x}$ & $\mathrm{x}$ & $\mathrm{x}$ & $\mathrm{x}$ & $\mathrm{x}$ & $\mathrm{x}$ & $\mathrm{x}$ & $\mathrm{x}$ & $\mathrm{x}$ & & & & & & & & & & & & & \\
\hline Living vs. Open & $\mathrm{x}$ & $\mathrm{x}$ & & $\mathrm{x}$ & $\mathrm{x}$ & $\mathrm{x}$ & $\mathrm{x}$ & $\mathrm{x}$ & $\mathrm{x}$ & & & $\mathrm{x}$ & $\mathrm{x}$ & $\mathrm{x}$ & $\mathrm{x}$ & $\mathrm{x}$ & $\mathrm{x}$ & $\mathrm{x}$ & $\mathrm{x}$ & $\mathrm{x}$ & $x$ & $\mathrm{x}$ & & & & & & & & & & & & & \\
\hline Dead vs. Open & $\mathrm{x}$ & $\mathrm{x}$ & & $\mathrm{x}$ & $\mathrm{x}$ & $\mathrm{x}$ & $\mathrm{x}$ & $\mathrm{x}$ & $\mathrm{x}$ & & & $\mathrm{x}$ & $\mathrm{x}$ & $\mathrm{x}$ & $\mathrm{x}$ & $\mathrm{x}$ & $\mathrm{x}$ & $\mathrm{x}$ & $\mathrm{x}$ & $\mathrm{x}$ & $\mathrm{x}$ & $\mathrm{x}$ & & & & & & & & & & & & & \\
\hline Meadow vs. Open & $\mathrm{x}$ & $\mathrm{x}$ & $\mathrm{x}$ & $\mathrm{x}$ & $\mathrm{x}$ & $\mathrm{x}$ & $\mathrm{x}$ & $\mathrm{x}$ & $\mathrm{x}$ & & & $\mathrm{x}$ & $\mathrm{x}$ & $\mathrm{x}$ & $\mathrm{x}$ & $\mathrm{x}$ & $\mathrm{x}$ & $\mathrm{x}$ & $\mathrm{x}$ & & $\mathrm{x}$ & $\mathrm{x}$ & & & & & & & & & & & & & \\
\hline
\end{tabular}

caused by defoliation. While the differences between the two sites were not very high in the first two winters after forest dieback (2013 and 2014), they clearly increased in winters 2015-2017. The mean SD differences during the first two winters were about $4 \mathrm{~cm}$. In winters 2015-2017 they increased to 7-8 cm (Table 1).

The SD data sets at different sites (snow courses) were statistically significantly different for most days with measurements (Table 2). The SD at site Open was always significantly different from that measured at the forested sites (Living, Dead).
SD in the open area located outside the forest (Meadow) did not have a consistent relation to the SD at sites located in the forest (Dead and Living). In winters 2013, 2014 and during the maximum snow depth period of winter 2016 it was higher, but in winters 2015 and 2017 it was similar (Fig. 3). Wind redistribution and solar radiation have the biggest influence at site Meadow. Therefore, the snow depth at this site is more dependent on weather conditions during any particular winter.

The SD data for the entire winters presented in Fig. 4 show that medians and most often also the first and third quartiles were increasing in the sequence Living $<$ Dead $<$ Meadow $<$ Open. 


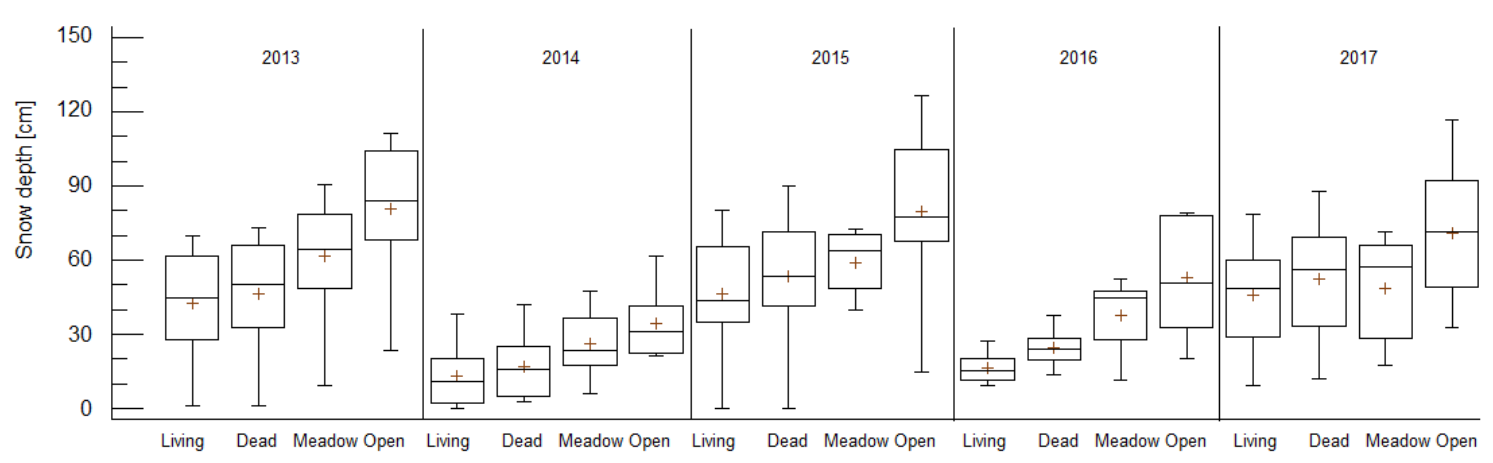

Fig. 4. Box-whisker plots (max-min, lower and upper quartiles, median) of the snow depth for the entire winters; the crosses show arithmetic mean.

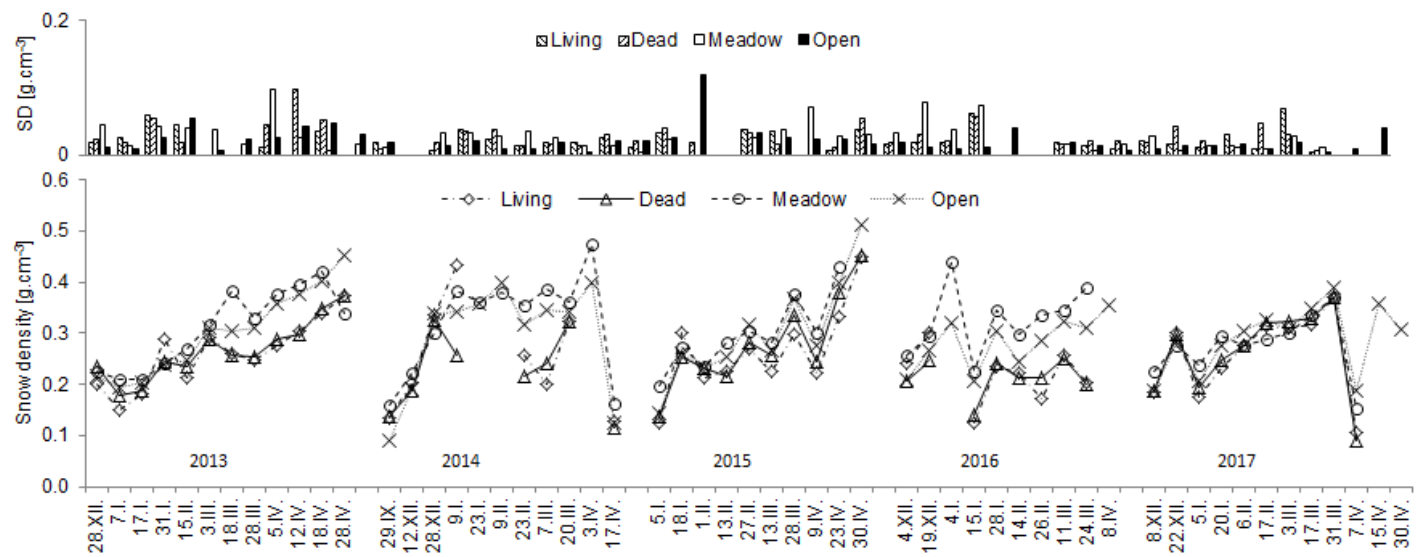

Fig. 5. Snow density and its within-site variability expressed by the standard deviation (SD).

The differences in the average snow SD over the winter were statistically significant with the exception of Living vs. Meadow and Dead vs. Meadow in winters 2015 and 2017. SD variability expressed by $\mathrm{Cv}$ at the forested sites (Dead, Living) was in most winters higher than at the sites located in open areas (Open, Meadow) (Table 1). An exception was observed in winter 2016 when the coefficients of variation of SD at the forested sites were smaller than in other winters.

\section{Snow density}

Snow density and its within-site variability expressed by the standard deviation are shown in Fig. 5. Maximum snow density was close to $0.5 \mathrm{~g} . \mathrm{cm}^{-3}$ and standard deviations were mostly below $0.05 \mathrm{~g} . \mathrm{cm}^{-3}$. Coefficients of variation of snow density were smaller than those of snow depth. Cvs of snow density on individual days with measurements were mostly below 0.15 . Temporal evolution and to some extent also differences in snow density among study sites reflected climatic conditions in individual winters. Favourable conditions, i.e. above-average precipitation and below-average sum of positive air temperatures in winter 2013 were reflected in the continuous increase of snow density. On the contrary, warm weather in winter 2014 resulted in a rapid increase of snow density to high values (wet snow) as early as December, and high variability due to thaws and new snow events afterwards. Fig. 5 also shows that snow density at sites without trees (Open, Meadow) was in most winters higher than at sites located in the forest (Living, Dead). This difference was clearly visible especially in the snowy winter 2013, and it was very small in winter 2017. Differences among particular sites were not large at the beginning of the accumulation period (fresh snow). Rapid decreases in snow density at the end of winter 2014 and at the beginning of April 2017 were caused by new snow following snowpack melt-out.

Snow density at site Dead was significantly different from that at site Living in 13 out of 48 days with data (Table 3 ). The mean snow density in the living forest was higher than that in the disturbed forest in 18 out of 48 days. However, larger differences $\left(>0.030 \mathrm{~g} . \mathrm{cm}^{-3}\right)$, were observed only in 6 cases. The differences in the remaining 12 cases varied from 0.002 to 0.016 g. $\mathrm{cm}^{-3}$. Such small differences can result from measurement error or natural variability of snow density along the snow course.

Snow density data for the entire winters (Fig. 6, Table 4) show that the main difference among the sites was between the forested and the open areas. The differences within these two groups, i.e. between the living and disturbed forest or between the forest opening and large open area were comparatively smaller. Winter 2017 was an exception, because snow densities at all sites were very similar. Differences in snow density between the disturbed and living forest for the entire winters were not statistically significant.

Unlike with snow depth, the coefficients of variation of snow density at the forested sites (Dead, Living) were often not very different from those in open areas (Open, Meadow). (cf. Tables 1 and 4).

\section{Snow water equivalent and the results from SWE modelling} (maximum SWE, snowmelt beginning and duration)

Summary statistics of measured SWE for all sites and the entire winters are presented in Fig. 7. SWE increased in the sequence Living $<$ Dead $<$ Meadow $<$ Open. As expected, open areas had higher SWE than the forested sites. Average SWE during the entire study period in the disturbed forest was about 
Table 3. Statistical significance of the differences in mean snow density among the sites.

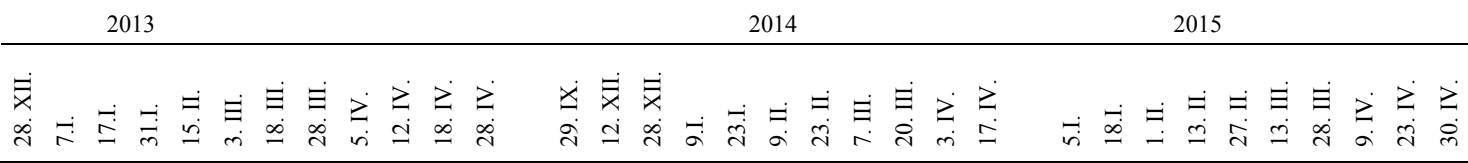

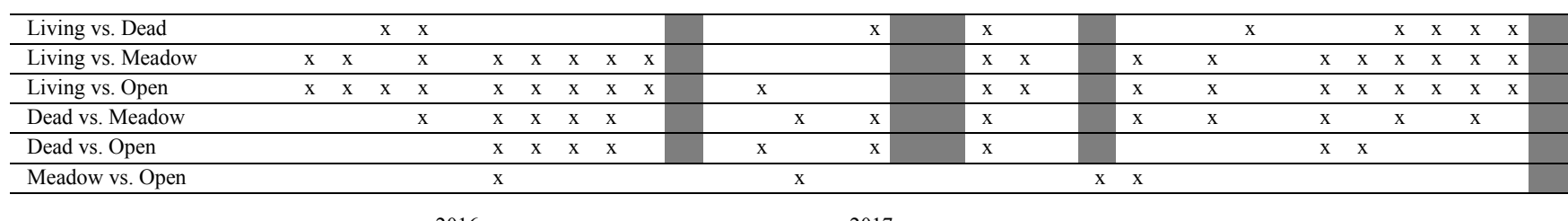

2016

\begin{tabular}{|c|c|c|c|c|c|c|c|c|c|c|c|c|c|c|c|c|c|c|c|c|}
\hline & $\begin{array}{l}\dot{\bar{x}} \\
\dot{+}\end{array}$ & $\begin{array}{l}\dot{\bar{x}} \\
\stackrel{2}{0}\end{array}$ & $\stackrel{+}{\dot{+}}$ & $\ddot{n}$ & $\underset{\infty}{\infty}$ & $\begin{array}{l}\dot{\Xi} \\
\dot{ \pm}\end{array}$ & $\begin{array}{l}\dot{\Xi} \\
\dot{\sim}\end{array}$ & $\begin{array}{l}\Xi \\
\Xi\end{array}$ & $\begin{array}{l}\Xi \\
\dot{J}\end{array}$ & $\underset{\infty}{\geq}$ & $\begin{array}{l}\dot{\bar{x}} \\
\infty\end{array}$ & $\begin{array}{l}\bar{x} \\
\text { ते }\end{array}$ & $\ddot{n}$ & $\ddot{\circ}$ & $\stackrel{\square}{\dot{0}}$ & $\begin{array}{l}= \\
\stackrel{\Xi}{\Xi}\end{array}$ & $\underset{\dot{m}}{\Xi}$ & 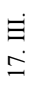 & $\begin{array}{l}\dot{\Xi} \\
\dot{m}\end{array}$ & $\underset{r}{i}$ \\
\hline Living vs. Dead & & $\mathrm{x}$ & & $\mathrm{x}$ & & & $\mathrm{x}$ & & & & & & & & & & & & & $\mathrm{x}$ \\
\hline Living vs. Meadow & & & & $\mathrm{x}$ & $\mathrm{x}$ & $\mathrm{x}$ & $\mathrm{x}$ & $\mathrm{x}$ & $\mathrm{x}$ & & $\mathrm{x}$ & $\mathrm{x}$ & $\mathrm{x}$ & $\mathrm{x}$ & & $\mathrm{x}$ & & $\mathrm{x}$ & & $\mathrm{x}$ \\
\hline Living vs. Open & & & & $\mathrm{x}$ & $\mathrm{x}$ & & $\mathrm{x}$ & $\mathrm{x}$ & $\mathrm{x}$ & & & & $\mathrm{x}$ & $\mathrm{x}$ & $\mathrm{x}$ & & & $\mathrm{x}$ & & $\mathrm{x}$ \\
\hline Dead vs. Meadow & & $\mathrm{x}$ & & $\mathrm{x}$ & $\mathrm{x}$ & $\mathrm{x}$ & $\mathrm{x}$ & $\mathrm{x}$ & $\mathrm{x}$ & & $\mathrm{x}$ & & $\mathrm{x}$ & $\mathrm{x}$ & & & $\mathrm{x}$ & & & $\mathrm{x}$ \\
\hline Dead vs. Open & & & & $\mathrm{x}$ & & & $\mathrm{x}$ & $\mathrm{x}$ & $\mathrm{x}$ & & & & & $\mathrm{x}$ & & & & & & $\mathrm{x}$ \\
\hline Meadow vs. Open & & & & & & & & & & & & & $\mathrm{x}$ & & $\mathrm{x}$ & $\mathrm{x}$ & & & & $\mathrm{x}$ \\
\hline
\end{tabular}

$\mathrm{x}$ - Significant difference at $95 \%$ level $\quad$-comparison is not available

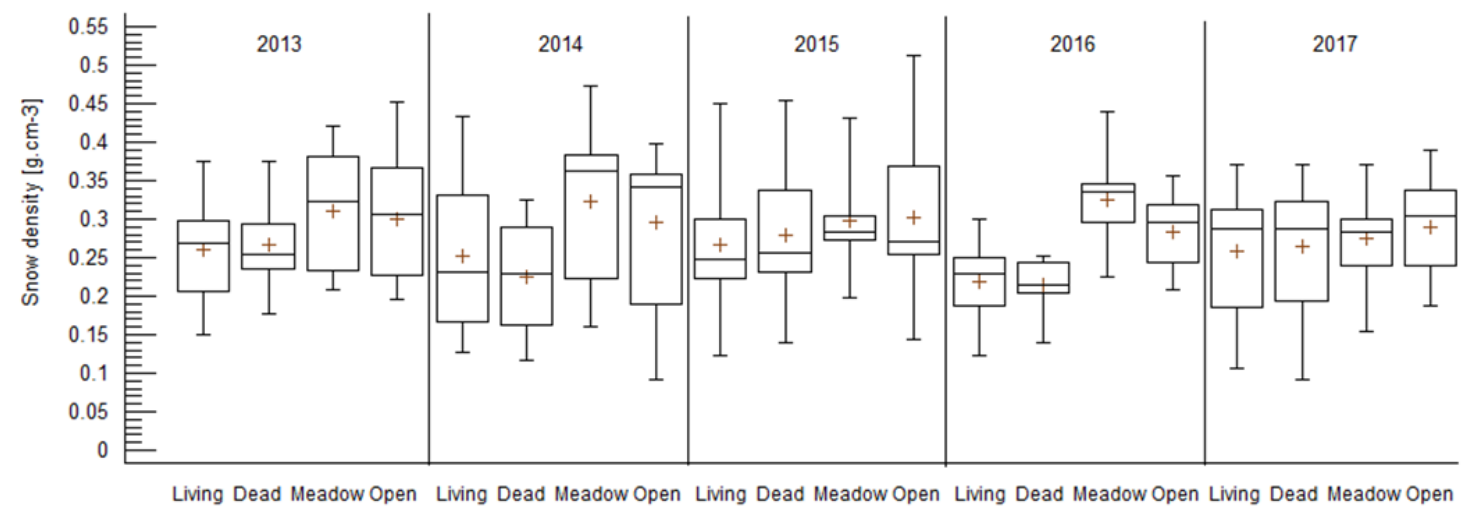

Fig. 6. Box-whisker plots (max-min, lower and upper quartiles, median) of snow density for the entire winters; the crosses show the arithmetic mean.

$25 \%$ higher than in the living forest. SWE in the forest opening was on average $31 \%$ higher than in the large open area (Meadow). This is in agreement with the finding that forest openings with widths about 1-2 times the canopy height (such as the opening in our study) have the most snow (Kittredge, 1953). SWE variability expressed by $\mathrm{Cv}$ increased in the opposite order as the SWE values, i.e. Open $<$ Meadow $<$ Dead $<$ Living. Similarly to snow density, the SWE variability within the two groups of sites (forested, open) was smaller than between them.

After visual comparison of measured and simulated SWE (Fig. 8) we have concluded that simulated SWE maxima and dates when the snowpack entirely melted were estimated reasonably well. A more detailed analysis of data reproduction is given later in the discussion.

Modelling results relevant to the theme of this article, i.e. the differences in snow accumulation and melt at different sites, are summarized in Table 5. They show that since winter 2015, maximum SWE in the disturbed forest was always greater than in the living forest. That corresponds to the increase in snow depth that started to become evident at the Dead site since the same winter. The final snowmelt phase, i.e. the snowmelt which ended with snow disappearence, started in the living

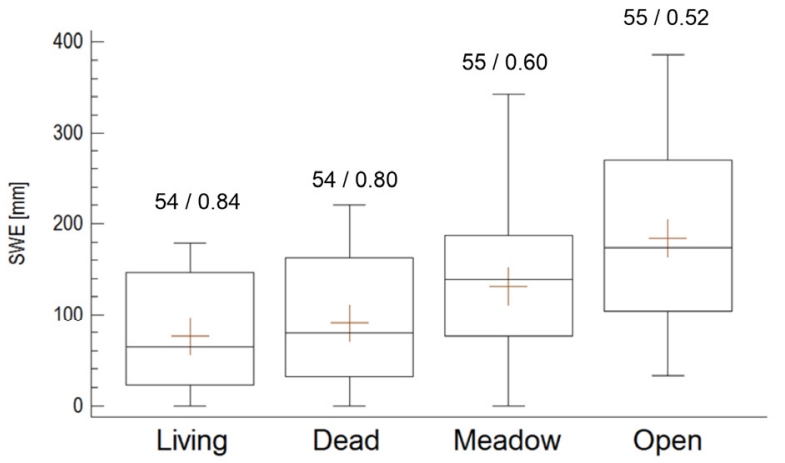

Fig. 7. Box-whisker plots (max-min, first and third quartiles, median) of measured SWE for all winters; the crosses show the arithmetic mean; the numbers above the graphs represent number of measurements (54-55) and coefficient of variation (0.52-0.84).

forest mostly later than in the disturbed forest (Dead), but the delay was only about 1-2 days. Although the SWE in the living forest was typically smaller than at other sites, the snow usually disappeared there approximately on the same days. 


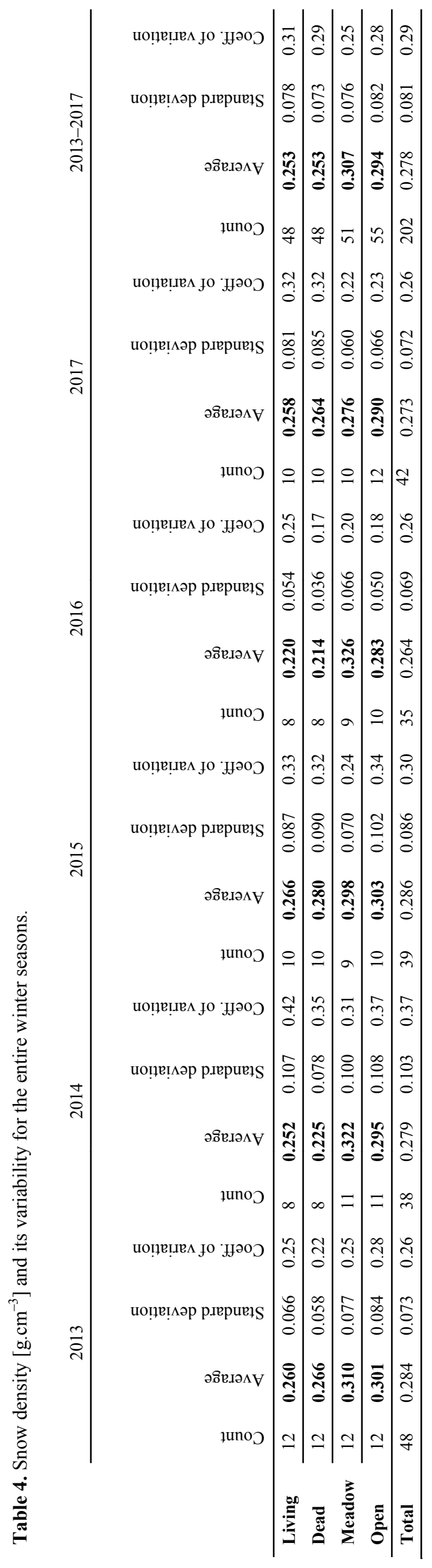

Measured data at the end of the snowmelt season were used to compare maximum snowmelt intensities at different sites during the precipitation free periods and corresponding degreeday factors obtained from both measured data and model calibration. Unfortunately, this was possible only for winter 2013, because precipitation occurred during maximum snowmelt intensity periods in all other winters. The results are presented in Table 6. Although the numbers from only one winter cannot be generalized, the results confirm that snowmelt intensity in the disturbed forest was higher than in the living forest. The largest snowmelt was observed in the forest opening. Snowmelt in the open areas (Open, Meadow) was almost $60 \%$ greater than at the forested sites (Living, Dead).

Degree-day factors for 18-28 April 2013 calculated from measured data were similar to those obtained during model calibration.

SWE in our study was significantly higher $(25 \%)$ in the disturbed forest than in the living forest. This difference is probably related to higher snow depth in the disturbed forest. However, unlike for snow depth, there was no significant SWE difference between the disturbed and living forest in individual winters (Fig. 8). Jeníček et al. (2018) did not directly compare SWE in the healthy and disturbed forest. However, they reported a smaller SWE difference (29\%) between open areas and defoliated spruce forest with standing trees compared to the difference between open area and healthy forest (45\%). This implies that the difference between the disturbed and healthy forest was $16 \%$. Boon (2012) concluded that snow density and SWE in disturbed and living forests are similar in high snow years while they are distinctly different in low-to-average snow years. However, their study was based only on two years of measured data. Pugh and Small (2012) reported 15\% more snow in a "grey phase stand" (needleless trees) than in a paired living stand. Their results are also based on two years of measured data at eight pairs of living and disturbed forest stands. Our data confirm the findings of Boon (2012) and Pugh and Small (2012) that the SWE difference between the disturbed and living forest is smaller for winters with higher snow accumulation (Fig. 9). Nevertheless, the SWE difference remained relatively high (about 20\%) also in winters with high snow accumulation (Fig. 9).

Evaluation of the snowmelt model efficiency by the objective function showed that KGE efficiency was high (between 0.7 and 1) for almost all simulations (Table 7). This is not surprising, because model parameters were changed independently for each site and winter to obtain the best simulation possible and we focused primarily on good reproduction of measured values on dates close to winter maximum SWE and during the ablation period. While model parameters based on such a strategy cannot be transferred to other sites or winters, we believe that SWE maxima and dates when the snow cover entirely melted were estimated reasonably well. However, detailed analysis of other simulated results such as the degree-day factors from such a modelling strategy is not meaningful. Table 7 shows that deleting one overestimated value at the beginning of the winter would significantly improve the KGE values for two of three simulations (sites Living and Dead in winter 2016). Analysis of the sources of modelling errors for site Meadow in winter 2015 (equation 2) showed that mean values of observed and corresponding simulated data were the same $(172 \mathrm{~mm})$ and the correlation coefficient was high (0.88). A low KGE value (0.008) resulted from the much higher standard deviation of the simulated data compared to that of observations. However, the observed values at the time of maximum measured SWE and 


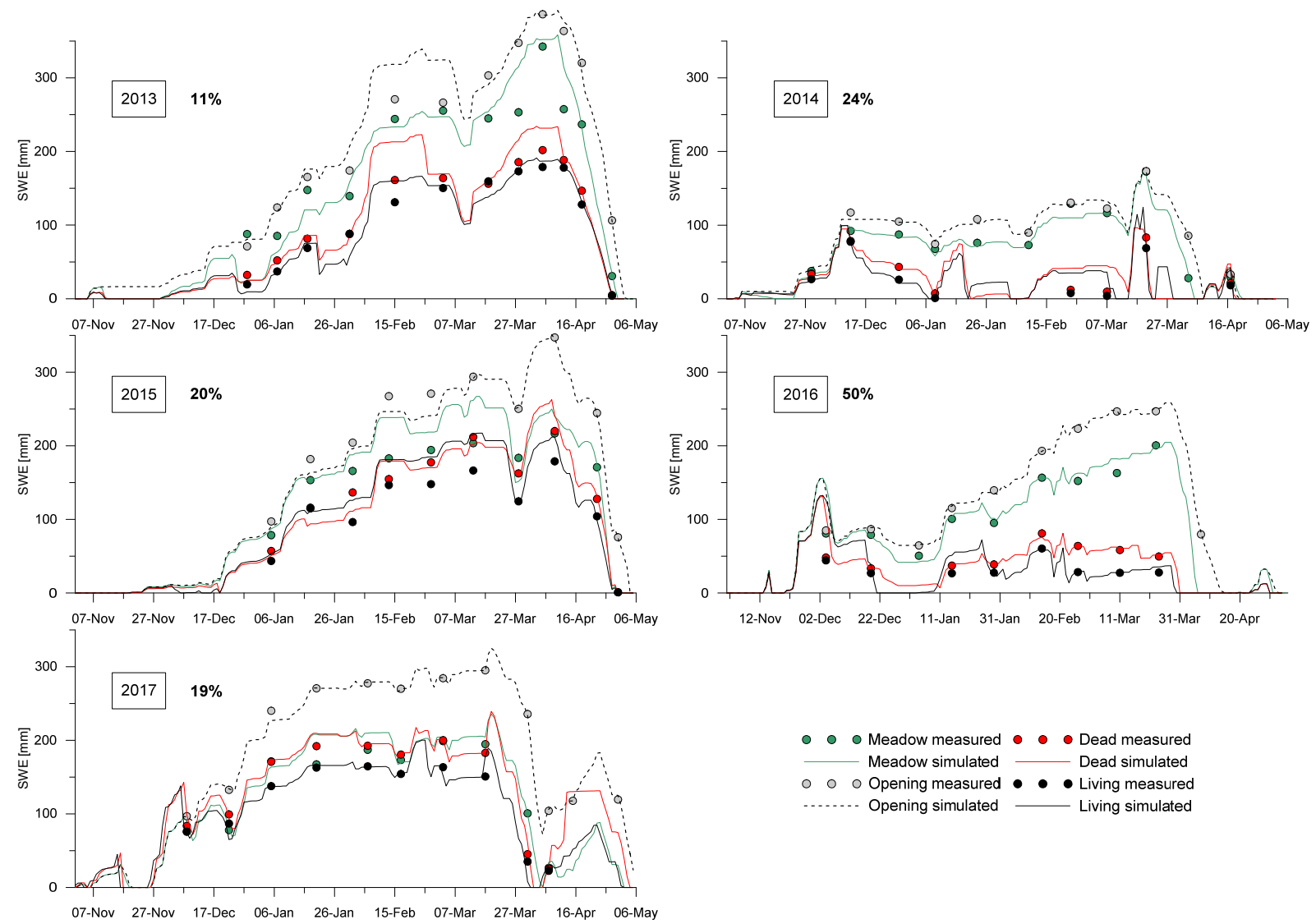

Fig. 8. Simulated and measured SWE in winters 2013-2017; the percentages show the amount by which the winter mean SWE in the disturbed forest (Dead) was greater than that in the living forest.

Table 5. Characteristics of snow accumulation and melt from snow modelling.

\begin{tabular}{|c|c|c|c|c|c|c|c|c|}
\hline \multirow[t]{2}{*}{ Winter } & \multicolumn{4}{|c|}{ Maximum snow water equivalent [mm] } & \multicolumn{4}{|c|}{ Snowmelt duration [days] } \\
\hline & Living & Dead & Meadow & Open & Living & Dead & Meadow & Open \\
\hline 2013 & 191 & 202 & 350 & 392 & 19 & 24 & 20 & 23 \\
\hline 2014 & 124 & 96 & 173 & 173 & 10 & 5 & 17 & 19 \\
\hline 2015 & 212 & 263 & 250 & 351 & 22 & 22 & 21 & 26 \\
\hline 2016 & 37 & 81 & 205 & 258 & 3 & 4 & 18 & 20 \\
\hline \multirow[t]{3}{*}{2017} & 189 & 239 & 236 & 325 & 45 & 46 & 44 & 48 \\
\hline & \multicolumn{4}{|c|}{ Snowmelt beginning } & \multicolumn{4}{|c|}{ Snowmelt end } \\
\hline & Living & Dead & Meadow & Open & Living & Meadow & Open & Dead \\
\hline 2013 & 10-Apr & $5-\mathrm{Apr}$ & 10-Apr & 10-Apr & 29-Apr & 30-Apr & 3-May & 29-Apr \\
\hline 2015 & 9-Apr & 8-Apr & 8-Apr & 8-Apr & 1-May & 29-Apr & 4-May & 30-Apr \\
\hline 2016 & 27-Mar & 28-Mar & 26-Mar & 26-Mar & 30-Mar & 13-Apr & 15-Apr & 1-Apr \\
\hline 2017 & 19-Mar & 19-Mar & 19-Mar & 19-Mar & 3-May & 2-May & 6-May & 4-May \\
\hline
\end{tabular}

the beginning of snowmelt were simulated moderately well (the differences between measured and simulated values were $10 \%$ and $3 \%$ ). Unlike in other winters, SWE close to snow disappearance was not measured at the Meadow site in winter 2015 (Fig. 8) which did not allow us to compare the measured and simulated values during the time of intensive ablation and which would probably improve the KGE value.

\section{DISCUSSION}

Our results revealed a statistically significant difference in SD between the living and disturbed forest which increased since the third winter after forest dieback. The difference in SD was most noticeable during snow maximum. These results cannot be directly compared with findings of other studies using measured snow characteristics in the disturbed forests, because most of them were based only on 1-2 years of data. Only Jeníček et al. (2018) had five years of data. They measured snow characteristics at 16 sites including 3 sites affected by the bark beetle. Although their measurements were conducted only 2-4 times per winter, the snowmelt periods were captured in all five winters. However, they did not evaluate the interannual evolution of SD differences in the living and disturbed forest.

Snow density in the disturbed and living forest was in most cases not significantly different. Jeníček et al. (2018) reported that compared to the healthy forest (an analog of the living forest in our study), snow density was slightly greater in the disturbed forest during the accumulation period. In contrast, snow density in the healthy forest was greater in the snowmelt period. Their conclusions were drawn from integrating the snow density data for the entire study period. Analogous data in our study reveal clear differences between the two groups of sites (forested versus open) while the differences within each group were smaller (Fig. 6, Table 4). 
Table 6. Snowmelt characteristics during the maximum snowmelt intensity period (18-28 April 2013); $\mathrm{DDF}_{\mathrm{obs}}$ and $\mathrm{DDF}_{\text {cal }}$ are degree-day factors calculated from the measured data and from model calibration, respectively

\begin{tabular}{|c|c|c|c|c|}
\hline Site & $\begin{array}{c}\text { Snowmelt } \\
\text { intensity } \\
{\left[\mathrm{mm}^{\left.-d_{a y}{ }^{-1}\right]}\right.}\end{array}$ & $\begin{array}{c}\text { Total } \\
\text { snowmelt } \\
{[\mathrm{mm}]}\end{array}$ & 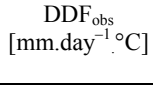 & 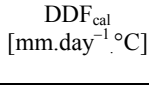 \\
\hline Living & 12.3 & 123 & 1.51 & 1.45 \\
\hline Dead & 14.3 & 143 & 1.76 & 1.80 \\
\hline Meadow & 20.6 & 206 & 2.53 & 2.50 \\
\hline Open & 21.4 & 214 & 2.63 & 2.40 \\
\hline
\end{tabular}

Table 7. Kling-Gupta efficiency coefficients; the values with asterisks represent $\mathrm{KGE}$ if one simulated value at the beginning of the snow season were omitted.

\begin{tabular}{|r|c|c|c|c|}
\hline Winter & Living & Dead & Meadow & Open \\
\hline 2013 & 0.902 & 0.773 & 0.692 & 0.942 \\
\hline 2014 & 0.821 & 0.833 & 0.901 & 0.93 \\
\hline 2015 & 0.695 & 0.952 & 0.008 & 0.959 \\
\hline 2016 & $-0.807\left(0.698^{*}\right)$ & $0.275\left(0.969^{*}\right)$ & 0.699 & 0.936 \\
\hline 2017 & 0.866 & 0.962 & 0.909 & 0.99 \\
\hline
\end{tabular}

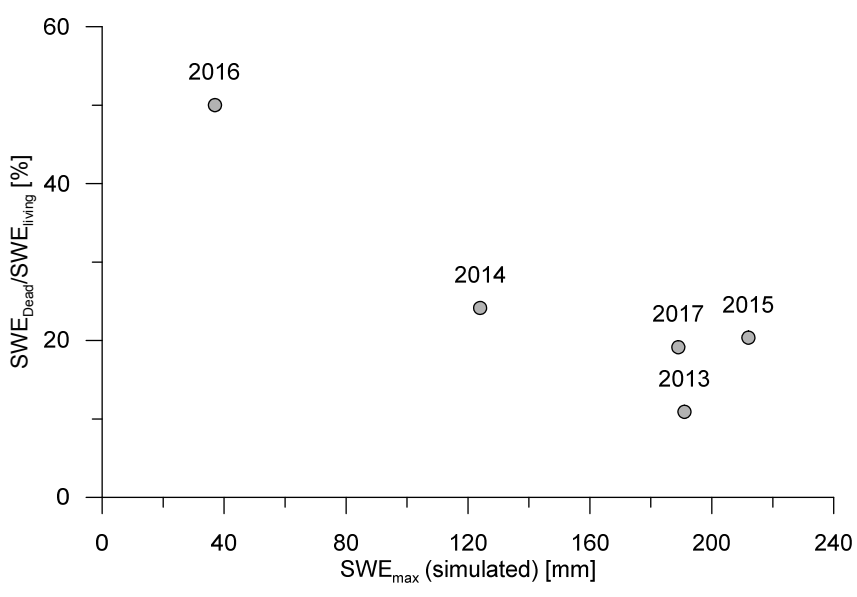

Fig. 9. The relationship between winter snow accumulation (simulated maximum SWE in the living forest at the beginning of the final snowmelt phase in $\mathrm{mm}$ ) and the percent difference in measured mean winter $\mathrm{SWE}$ in the disturbed $\left(\mathrm{SWE}_{\mathrm{Dead}}\right)$ and living forest (SWE $E_{\text {Living }}$ ) for winters $2013-2017$; a value of $50 \%$ on the vertical axis means that mean SWE in the disturbed forest was $50 \%$ greater than that in the living forest.

Snowmelt intensity in the disturbed forest based on measured data from the end of winter 2013, i.e. the first winter after forest dieback (and the high-snow winter), was 16\% higher than in the living forest (Table 6). This was an expected result because forest dieback increases incoming solar radiation. Jeníček et al. (2018) reported a similar difference (18\%). Their value was based on simulated degree-day factors for five winters. Our preference of using measured instead of simulated values means that we could compare the data from only one of the five winters. In other winters, either the SWE was not measured on days close to the snow disappearance or the snowmelt was affected by precipitation. Thus, it was not possible to investigate the evolution of the differences in ablation rates with time elapsed since the forest dieback. Simulated SWEs indicated that the mean ablation intensities at the end of winters 2013-2017 in the living and disturbed forest were similar, and ablation at the Meadow and Open sites were on average $7 \%$ and $16 \%$ higher than at forested sites, respectively. However, because we had only five values (winters) for each site and the values in individual winters varied, the comparison of the mean values of ablation rates obtained from the modelling is not meaningful.

\section{CONCLUSIONS}

This article presents the results of longer-term (five winters) and relatively frequent (every two weeks) measurements of snow characteristics at four sites with different land cover. The main focus was the differences between the living and disturbed forest. Snow depth was significantly greater in the disturbed forest and the difference increased since the third winter after dieback. Differences in snow density were in most cases not significant. Differences in snow water equivalent (SWE) reflected differences in snow depth, although the progressive increase during the study period (as in the case of snow depth) was not observed. Average SWE over the entire study period in the disturbed forest was $25 \%$ greater than in the living forest stand. This indicates that the amount of water accumulated in snow in areas affected by large-scale forest dieback could significantly increase. Higher snow accumulation does not necessarily mean that total runoff or flood peaks would be higher (Jeníček et al., 2018). Results of our plot-scale simulations did not indicate significant differences in snowmelt characteristics between the disturbed and living forest. Although the SWE in the living forest was smaller and its variability was greater, the beginning of the final snowmelt phase and the date of snow disappearance at the two stands were similar. However, timing of snowmelt runoff events can change if large parts of originally forested catchments are affected by forest dieback due to higher ablation rates in the disturbed forest. This scenario can be tested in follow-up modelling studies validated against the measured values from the plot-scale data.

Acknowledgements. This work was accomplished as part of VEGA projects No.: 1/0367/16, 1/0589/15, 1/0463/14 and 2/0055/15 of the Ministry of Education, Science, Research and Sport of the Slovak Republic and the Slovak Academy of Science; and the projects of the Slovak Research and Development Agency No.: APVV-0423-10, APVV-0303-11, APVV-15-0425 and APVV-15-0497. We would like to acknowledge also financial support from the European Regional Development Fund Project 26220120062 "Centre of excellence for the integrated river basin management in changing environmental conditions" which allowed purchase of the equipment used in this study. We are grateful to Dr. J. Shanley for the improvement of English.

\section{REFERENCES}

Adams, H.D., Luce, C.H., Breshears, D.D., Allen, C.D., Weiler, M., Hale, V.C., Smith, A.M.S., Huxman, T.E., 2012. Ecohydrological consequences of drought- and infestation-triggered tree die-off: insights and hypotheses. Ecohydrology, 5, 145-159.

Anderson, H.W., 1963. Managing California's Snow Zone Lands for Water. U.S. Forest Service Research Paper PSW-6, 28 p.

Bartík, M., Sitko, R., Oreňák, M., Slovik, J., Škvarenina, J., 2014. Snow accumulation and ablation in disturbed mountain spruce forest in West Tatra Mts. Biologia, 69, 1492-1501.

Bartík, M., Jančo, M., Střelcová, K., Škvareninová, J., Škvarenina, J., Mikloš, M., Vido,J., Dagsson Waldhauserová, P., 2016. Rainfall interception in a disturbed montane spruce (Picea abies) stand in the West Tatra Mountains. Biologia, 71, 10021008.

Boon, S., 2012. Snow accumulation following forest disturbance. Ecohydrology, 5, 279-285. 
Bredemeier, M., Cohen, S., Godbold, D.L., Lode, E., Pichler, V., Schleppi, P. (Eds.)., 2010. Forest Management and the Water Cycle: An Ecosystem-Based Approach (Vol. 212). Springer Science \& Business Media. 531 p.

Celer, S., 2013. Forest in the Jalovecká dolina valley In: Divočina pod Salatínom. REPROservis, Liptovský Mikuláš, pp. 81-104. (In Slovak.) ISBN 978-80-971499-9-4

Church, J.E., 1914. Recent studies of snow in the United States. Quart. Jour. Royal Met. Soc., 40, 169, 43-52.

Elias, V., Tesar, M., Buchtele, J., 1995. Occult precipitation: sampling, chemical analysis and process modelling in the Sumava Mts. (Czech Republic) and in the Taunus Mts. (Germany). Journal of Hydrology, 166, 409-420.

Ellis, C.R., Pommeroy, J.W., Brown, T., MacDonald, J., 2010. Simulation of snow accumulation and melt in needleleaf forest environments. Hydrol. Earth Syst. Sci. Discuss., 7, 1033-1072.

Fišák, J., Řezáčová, D., Eliáš, V., Tesař, M., 2001. Comparison of pollutant concentrations in fog (low cloud) water in Northern and Southern Bohemia. Journal of Hydrology and Hydromechanics, 49, 275-290.

Fleischer, P., Pichler, V., Fleischer, P. Jr., Holko, L., Máliš, F., Gömöryová, E., Cudlín, P., Michalová, Z., Homolová, Z., Škvarenina, J., Střelcová, K., Hlaváč, P., 2017. Forest ecosystem services affected by natural disturbances, cliamte and land-use changes in the Tatra Mountains. Climate Research, 73, 57-71.

Garstka, W.U., Love, L.D., Goodell, B.C., Bertle, F.A., 1958. Factors affecting snowmelt and streamflow. U.S. Bureau of Reclamation and U.S. Forest Service, 189 p.

Golding, D.L, Swanson, R.H., 1986. Snow distribution patterns in clearings and adjacent forest. Water Resources Research, 22, $13,1931-1940$

Gömöryová, E., Střelcová, K., Škvarenina, J., Gömöry, D., 2013. Responses of soil microorganisms and water content in forest floor horizons to environmental factors. European Journal of Soil Biology, 55, 71-76.

Gömöryová, E., Fleischer, P., Pichler, V., Homolák, M., Gere, R., Gömöry, D., 2017. Soil microorganisms at the windthrow plots: The effect of postdisturbance management and the time since disturbance. IForest, 10, 515-521.

Grodzki, W., Jakuš, R., Lajzová, E., Sitková, Z., Maczka, T., Škvarenina, J., 2006. Effects of intensive versus no management strategies during an outbreak of the bark beetle Ips typographus (L.)(Col.: Curculionidae, Scolytinae) in the Tatra Mts. in Poland and Slovakia. Annals of Forest Science, 63, 55-61.

Gupta, V.H., Kling, H., Yilmaz, K.K., Martinez, F.G., 2009. Decomposition of the mean squared error and NSE performance criteria: Implications for improving hydrological modelling. Journal of Hydrology, 377, 81-90.

Harpold, A.A., Biederman, J.A., Condon, K., Merino, M., Korgaonkar, Y., Nan, Y., Sloat, L.L., Ross, M., Brooks, P.D., 2014. Changes in snow accumulation and ablation following the Las Conchas forest fire, New Mexico, USA. Ecohydrology, 7, 440 452.

Hlaváčiková, H., Novák, V., Šimůnek, J., 2016. The effects of rock fragment shapes and positions on modeled hydraulic conductivities of stony soils. Geoderma, 281, 39-48.

Holko, L., Kostka, Z., 2010. Hydrological processes in mountains - knowledge gained in the Jalovecky Creek catchment, Slovakia. In: Proc. of the Workshop "Status and Perspectives of Hydrology in Small Basins" held at Goslar-Hahnenklee, Germany, 30 March-2 April 2009. IAHS Publ. 336. IAHS Press, Wallingford, pp. 84-89.

Holko, L., Škvarenina, J., Kostka, Z., Frič, M., Staroň, J., 2009. Impact of spruce forest on rainfall interception and seasonal snow cover evolution in the Western Tatra Mountains, Slovakia. Biologia, 64, 594-599.

Holko, L., Danko, M., Kostka, Z., 2012. Classification of winters, density of the new snow and the degree-day factor in the Jalovecký creek catchment. Acta Hydrologica Slovaca, 13, 2,
342-349. (In Slovak with an English abstract and summary.)

Chang, M., 2006. Forest Hydrology: An Introduction to Water and Forests, Second Edition. CRC Press, Taylor \& Francis group, Boca Raton, London, New York, 488 p.

Jakuš, R., Zajíčkova, L., Cudlín, P., Blaženec, M., Turčani, M., Ježík, M., Lieutier, F., Schlyter, F., 2011. Landscape-scale Ips typographus attack dynamics: From monitoring plots to GISbased disturbance models. IForest, 4, 256-261.

Janda, P., Trotsiuk, V., Mikolas, M., Bace, R., Nagel, T., Seidl, R., Seedre, M., Morrissey, R.C., Kucbel, S., Jaloviar, P., Jasik, M., Vysoky, J., Samonil, P., Cada, V., Mrhalova, H., Labusova, J., Novakova, M., Rydval, M., Mateju, L., Svoboda, M., 2016. The historical disturbance regime of mountain Norway spruce forests in the Western Carpathians and its influence on current forest structure and composition. Forest Ecology and Management, 388, 67-78.

Jenicek, M., Pevna, H., Matejka, O., 2018. Canopy structure and topography effects on snow distribution at a catchment scale: Application of multivariate approaches. J. Hydrol. Hydromech., $66,1,43-54$.

Jewitt, G., 2005. Water and forests. In: Anderson, M.G., McDonnell, J.J. (Eds.): Encyclopedia of Hydrological Sciences, Chapter 186. John Wiley \& Sons, Ltd., pp. 2895-2909.

Kittredge, J., 1953. Influence of forests on snow in the PonderosaSugar pine-fir zone of the Central Sierra Nevada. Hilgardia, 22, 1, 1-96.

Koivusalo, H., Kokkonen, T., 2002. Snow processes in a forest clearing and in a coniferous forest. Journal of Hydrology, 262, $145-164$.

Krajčí, P., Holko, L., Parajka, J., 2016. Variability of snow line elevation, snow cover area and depletion in the main Slovak basins in winters 2001-2014. Journal of Hydrology and Hydromechanics, 64, 1, 12-22.

Kuusisto, E., 1980. On the values and variability of degree-day melting factor in Finland. Nord. Hydrol., 11, 235-242.

Lundberg, A., Calder, I., Harding, R., 1998. Evaporation of intercepted snow: measurement and modelling. J. Hydrol., 206, 151163.

Mayer, H., Feger, K.H., Ackertvlann, B., Armbruster, M., 1997. Schneedeckenentwicklung in Fichtenwäldern im südlichen Hochschwarzwald. Forstw. Cbl., 116, 370-380.

Mezei, P., Grodzki, W., Blaženec, M., Škvarenina, J., Brandýsová, V., Jakuš, R., 2014. Host and site factors affecting tree mortality caused by the spruce bark beetle (Ips typographus) in mountainous conditions. Forest Ecology and Management, 331, 196-207.

Mezei, P., Jakuš, R., Pennerstorfer, J., Havašová, M., Škvarenina, J., Ferenčík, J., Slivinský, J., Bičárová, S., Bilčík, D., Blaženec, M., Netherer, S., 2017. Storms, temperature maxima and the Eurasian spruce bark beetle Ips typographus - An infernal trio in Norway spruce forests of the Central European High Tatra Mountains. Agricultural and Forest Meteorology, 242, 85-95.

Michalová, Z., Morrrissey, RC, Wohlgemuth, T., Bače, R., Fleischer, P., Svoboda, M., 2017. Salvage logging after windstorm leads to structural and functional homogenisation of understory layer and delayed spruce tree recovery in Tatra Mts., Slovakia. Forests, 8, 88. DOI: 10.3390/f8030088.

Mind’áš, J., Škvarenina, J., 1995. Chemical composition of fog cloud and rain snow water in Biosphere Reserve Pol'ana. Ekologia-Bratislava, 14, 125-137.

Mráček, Z., Krečmer, V., 1975. Význam lesa pro lidskou společnost. SZN. 225 p. (In Czech.)

Nash, J.E., Sutcliffe, J.V., 1970. River flow forecasting through conceptual models, Part I - A discussion of principles. Journal of Hydrology, 10, 282-290.

Oreňák, M., Vido, J., Hríbik, M., Bartík, M., Jakuš, R., Škvarenina, J., 2013. Interception process of spruce forest in the phase of disintegration in the Western Tatras (Západné Tatry), Slovakia. Zpravy Lesnickeho Vyzkumu, 58, 360-369. (In Slovak.) 
Parobeková, Z., Sedmáková, D., Kucbel, S., Pittner, J., Jaloviar, P., Saniga, M., Balanda, M., Vencurik, J., 2016. Influence of disturbances and climate on high-mountain Norway spruce forests in the Low Tatra Mts., Slovakia. Forest Ecology and Management, 380, 128-138.

Perrot, D., Molotch, P., Musselman, N., Pugh, T., 2012. Modelling the effects of the mountain pine beetle on snowmelt in a subalpine forest. Ecohydrol., 7, 226-241.

Pugh, E., Small, E., 2012. The impact of pine beetle infestation on snow accumulation and melt in the headwaters of the Colorado River. Ecohydrol., 5, 467-477.

Rogger, M., Agnoletti, M., Alaoui, A., Bathurst, J.C., Bodner, G., Borga, M., Chaplot, V., Gallart, F., Glatzel, G., Hall, J., Holden, J., Holko, L., Horn, R., Kiss, A., Kohnová, S., Leitinger, G., Lennartz, B., Parajka, J., Perdigao, R., Peth, S., Plavcová, L., Quinton, J.N., Robinson, M., Salinas, J.L., Santoro, A., Szolgay, J., Tron, S., van den Akker, J.J.H., Viglione, A., Blöschl, G., 2017. Land use change impacts on floods at the catchment scale: Challenges and opportunities for future research. Water Resour. Res., 53. DOI:10.1002/2017WR020723.

Seidl, R., Schelhaas, M.J., Lexer, M.J., 2011. Unraveling the drivers of intensifying forest disturbance regimes in Europe. Global Change Biology, 17, 2842-2852.

Stähli, M., Papritz, A., Waldner, P., Forster, F., 2000. Die Schneedeckenverteilung in einem voralpinen Einzugsgebiet und ihre Bedeutung für den Schneeschmelzabfluss. Schweiz. Z. Forstwes., 151, 6, 192-197.

Stähli, M., Badoux, A., Ludwig, A., Steiner, K., Zappa, M. Hegg, C., 2011. One century of hydrological monitoring in two small catchments with different forest coverage. Environmental Monitoring and Assessment, 174, 91-106. DOI: 10.1007/s10661010-1757-0.
Swanson, R.H., Golding, D.L., 1982. Snowpack management on Marmot waterhsed to increase late season streamflow. In: Proc. Western Snow Conference 1982, pp. 215-218.

Troendle, C.A., King, R.M., 1985. The effect of timber harvest on the Fool Creek Watershed, 30 years later. Water Resources Research, 21, 12, 1915-1922.

Troendle, C.A., King, R.M., 1987. The effect of partial and clearcutting on streamflow at Deadhorse Creek, Colorado. J. Hydrol., 90, 145-157.

Varhola, A., Coops, N.C., Weiler, M., Moore, D.R., 2010. Forest canopy effects on snow accumulation and ablation: An integrative review of empirical results. Journal of Hydrology, 392, 219-233.

Vido, J., Tadesse, T., Šustek, Z., Kandrík, R., Hanzelová, M., Škvarenina, J., Škvareninová, J., Hayes, M., 2015. Drought occurrence in central european mountainous region (Tatra National Park, Slovakia) within the period 1961-2010. Advances in Meteorology, 2015, Article ID 248728, 8 p. DOI: $10.1155 / 2015 / 248728$.

Winkler, R., Boon, S., Zimonick, B., Spittlehouse, D., 2014. Snow accumulation and ablation response to changes in forest structure and snow surface albedo after attack by mountain pine beetle. Hydrological Processes, 28, 197-209.

Zelený, V., 1971. The effect of the spruce stand reneval by clearing on the snow conditions. Vodohospodársky časopis (J. Hydrol. Hydromech.), 19, 6, 571-590. (In Czech with an English abstract.)

Received 23 October 2017 Accepted 22 April 2018 